\title{
Routing for safer rides: a space syntax approach to predict bicycle collisions in a Brazilian city
}

\author{
Rotas para viagens mais seguras: uma abordagem da \\ sintaxe espacial para prever acidentes de bicicleta em uma \\ cidade brasileira
}

Danaê Fernandes [a] [D, Mariana Ragassi Urbano [a] [D], Milena Kanashiro [a] [D]

[a] Universidade Estadual de Londrina (UEL), Londrina, PR, Brasil

How to cite: Fernandes, D., Urbano, M. R., \& Kanashiro, M. (2021). Routing for safer rides: a space syntax approach to predict bicycle collisions in a Brazilian city. urbe. Revista Brasileira de Gestão Urbana, v.13, e20200106. https://doi.org/10.1590/2175-3369.013.e20200106

\begin{abstract}
In order to broaden the discussion on the safety of bicycle transport, this paper uses the analytical capacity of the spatial syntax applied to the recording of accidents involving cyclists in the city of Rolândia-PR, located in the Southern Region of Brazil. With the availability of 535 reports of trips made by bicycle mode, collected in the survey origin and destination of the city, a database was elaborated where each segment of the road received its numerical value from the loading of trips, and its corresponding values of choice and integration, generated in the Depthmap software. As a result, the relationship between the point of accident and the trip record by bicycle was refuted. In contrast, the angular values of choice and integration were sufficient to explain the occurrence of accidents involving cyclists in each segment of the municipal urban network, statistically proven through the generation of a generalized linear model. The contribution of this study focuses on the validity of using spatial syntax to predict safer routes, which is considered a theoreticalmethodological approach that identifies priority routes for the implementation of specific infrastructure for bicycle transport.
\end{abstract}

Keywords: Bikeability. Cyclability. Safety.

\section{Resumo}

Com o intuito de ampliar a discussão sobre a segurança do transporte por bicicleta, o presente trabalho utiliza a capacidade analítica da sintaxe espacial aplicada ao registro de ocorrências de acidentes envolvendo ciclistas na cidade de Rolândia-PR, localizada na Região Sul do Brasil. Com a disponibilidade de 535 relatos de viagens realizadas pelo modo bicicleta, coletadas na pesquisa origem destino domiciliar do município, elaborou-se um banco de dados onde cada segmento de via recebeu seu valor numérico do carregamento de viagens, e seus

DF is an architect and urban planner, master's in architecture and Urbanism. e-mail: daenandes@gmail.com MRU is a statistician, professor, PhD in Agronomy (Agricultural Statistics and Experimentation), e-mail: mrurbanouel@gmail.com MK is an architect and urban planner, professor, PhD in Environment and Development, e-mail: milena@uel.br 
valores correspondentes de escolha e integração, gerados no software Depthmap. Como resultado, foi refutada a relação entre o ponto de ocorrência de acidente e o registro de viagem por bicicleta. Em contrapartida, os valores angulares de escolha e integração foram suficientes para explicar a ocorrência de acidentes envolvendo ciclistas em cada segmento da malha urbana municipal, comprovados estatisticamente através da geração de um modelo linear generalizado. Como contribuição, aponta-se a validade de utilização da sintaxe espacial para prever rotas mais seguras, considerada uma abordagem teórico-metodológica capaz de apontar vias prioritárias para a construção de infraestrutura específica para o transporte por bicicleta.

Palavras-chave: Ciclabilidade. Ciclável. Segurança.

\section{Introduction}

The bicycle is considered a mode of transport that should be enhanced, as it complies with the principles of environmental, social and economic sustainability (Gössling, 2016). Efforts for efficient urban commuting by bicycle are unanimous in the scientific literature, which points out different ways of achieving this same goal, whether through speed (Ellison \& Greaves, 2011), travel time (McNeil, 2011), security (Vandenbulcke et al., 2014), intermodality and sharing (Boullier \& Crépel, 2014), service level (Lowry et al., 2012) or route preferences (Vedel et al., 2017).

Combining efficiency with low impact on the environment, it is possible to make "door-to-door" shifts in order to compete with motorised modes of transport over distances of less than $5 \mathrm{~km}$, without using fossil fuels and occupying less urban space (Litman, 2014).

As a low-polluting transport alternative with physical activity, the use of bicycle transport on daily trips is associated with a reduced risk of cancer, cardiovascular diseases and metabolic syndromes (Celis-Morales et al., 2017), and therefore inserts on urban agendas to improve public health.

For Ahmad \& Oliveira (2016), investment in bicycle transport quality is strategic, especially in developing countries, due to its increasing motorisation rates and the fact that it faces urban transport crises. As a mode of transport to be supported, the bicycle has advantages and potential, meeting the socioeconomic needs of the population living in developing countries, since great disparities in access to transport systems can be noted among social segments, especially Latin American countries, such as Brazil, for example (Maricato, 2014).

Although there is a growing interest in inserting the bicycle into the urban transport network, there are impediments to its full implementation. Among middle-income countries, Brazil has one of the highest transport accident mortality rates in the world (WHO, 2013). Among the victims in urban areas, most are non-motorised transport users, i.e. pedestrians and cyclists (The World Bank, 2002).

Safety is considered a decisive factor for urban cyclability (Wahlgren \& Schanz, 2011), and may even annul the possibility of choosing the bicycle as transport (Habib et al., 2014). For Steil Ferraz et al. (2017), bicycle safety is an essential component for the development of bicycle transport, which in turn improves the quality of cities with healthier journeys based on non-motorised mobility.

Whereas bicycle infrastructure can function like a magnet for this type of transport (Schoner et al., 2015), it is important to direct efforts in the understanding of the factors that provide safety to bicycle travel, in order to encourage this mode of travel in emerging countries.

Considering that traditional traffic models are not considered sufficient to predict the behaviour of cycling throughout the urban scale (Cooper, 2017), a broad approach to the phenomenon of cycling is the analysis of the spatial configuration of the built environment.

According to Law et al. (2014), the interaction between urban form and cycling is a field where spatial syntax has proven useful as an analysis tool. The combined use of geoprocessing and spatial syntax has shown positive results in improving cycle routes (Nordström \& Manum, 2015) and in calculating the volume of cyclists on urban roads (Raford et al., 2007).

The objective of this work is to prove the usefulness of spatial syntax for forecasting vehicle-bicycle accidents in a medium-sized city in a developing country. To achieve this, the positive associations between 
spatial syntax and cycling trips already available in literature are considered for a specific application on the safety of municipal-scale bicycle transport, developing a correlational study between urban networks and the susceptibility to accidents involving cyclists.

It is noticed that are limited numbers of studies of cycling movement patterns in the context of newly industrialized countries, and that there are disagreements about where to locate specific infrastructure for bicycle transport in these locations. Thus, the work seeks to enter into discussions of urban planning and road safety, in order that the construction of infrastructure specific to bicycle transport has a greater analytical basis in Brazil.

Aware there are controversies in Brazil concerning technical and political issues in cycling infrastructure planning, but that society's movement has required better-designed bicycle lanes (Duarte et al., 2014), we must question the arbitrariness of the choice of roads with specific infrastrucuture for bicycles, often guided only by the availability of road space and not by offering fast, direct and safe travel.

In this sense, a debate should be opened about cities being fully cyclable, even if we have to concentrate efforts on strategic avenues so that changes can be made to a safer behaviour towards bicycles. With the possibility of identifying routes with high accident potential through a mathematical equation derived from space syntax, the identification of these strategic routes can be based on accident prevention, which is the object of this work.

\section{Space syntax and bicycle transport}

Space syntax is a theoretical-methodological approach with a set of techniques for analyzing urban and architectural space, based on the precept that any normative provision is only valid when indicated by an analytical method. For Hillier (1996), theories of architecture and urbanism with purely normative content, saying how the city should be made, are not sustained because they distance themselves from the analytical essence of science.

Thus, the spatial syntax began with the proposal to understand, in an analytical way, the influence of architectural design on social problems (Oliveira, 2016). The descriptive autonomy of space is considered, where patterns of the built environment are related to human behavior. In this way, the syntax does not prescribe models of urban networks, but it helps to improve their qualities and functioning.

For space syntax, the movement of people is clearly influenced by how a city's street system is organized. Each street has a certain position in the road system of each city, so it has a certain potential to receive human displacement.

As a main characteristic, the spatial relationships with the urban area are translated into line or axis maps. Through the use of software, accessibility, integration and connectivity measures are calculated for each track segment, according to the logarithmic relationship of the whole system.

With this, one of the innovations is the correlation between urban space and flow, with developments for transportation planning. Contradicting theories based on the attraction of land use, the space syntax considers that the movement of people influences the use of the land and therefore is the most important element to be considered. Thus, it is understood that the urban configuration is, in itself, generating patterns of human movement.

According to Manum et al. (2017), the interaction between urban form and bicycle path behavior is a field where space syntax has proven useful as a tool for analysis. For bicycle displacements, the measure of choice was found to be the most promising (McCahill \& Garrick, 2008), including for demand prediction (Raford et al., 2007). To calculate this measure, all points in the urban network are treated as origins and destinations, and the most direct connections receive higher values, indicating more agile and efficient paths for cycling.

For Hillier et al. (2012), the measure of choice has the ability to determine the number of routes in a system that cross a particular space in the urban grid, while the measure of integration calculates the distance of each spatial element from all others in the system. The union of these measures can help in the 
understanding of accessibility for bicycle transport (Law et al., 2014), and might have its values combined in the Depthmap software as presented in this work. Depthmap is a spatial analysis software developed by the Space Syntax group of Bartlett School of Architecture, London's Global University. It is an open-source software, available as depthmapX, in version 0.6.0.

\section{Cycling-specific infrastructure}

Between bicycle lanes, cycle lanes and shared lanes, it is considered that there are controversies about the ideal type of cycling infrastructure (Eliou \& Galanis, 2009), however, there is consensus on the positive relationship between exclusive lanes for bicycles and cycling rates (Buehler \& Dill, 2015). For Guthrie et al. (2001), bicycle infrastructure cannot create new problems and disadvantages for the cyclist, notably delays and additional crossings.

In the study conducted by Lowry et al. (2016), it is clear that bicyclists travelling for utilitarian purpose choose routes that will minimize impedance or generalized cost, wich is a combination of distance, traffic stress and slope. Local streets are pointed out as uncomfortable, since they require frequent stops, with constant acceleration resumption, using too much energy for displacement.

Using transport-economic theory, Nielsen et al. (2013) determine that cycling speed is an important cost variable, since the high probability of cycling is explained by the convenience of the bicycle as a mode of travel, which includes travel time.

However, when addressing the high exposure of cyclists to black carbon particles on bus routes, Krecl et al. (2019) guide Brazilian urbanists to keep the circulation of bicycles away from collector and arterial roads, since the country uses buses with old and highly polluting technologies. Minikel (2012) also points out the removal of cyclists from arterial roads, prioritizing road safety. In this sense, it is noted that there are conflicting recommendations in the detection of priority routes for cyclable infrastructure.

There are contradictions in the practical and theoretical implications on the identification of routes that should be endowed with specific infrastructure, now hovering towards travel efficiency, aiming at reducing journey times (Halldórsdóttir et al., 2017), or valuing green areas and beautiful landscapes (Wahlgren \& Schantz, 2012).

The answer, perhaps, lies in the work of Lowry \& Loh (2017). For the authors, the existence of cycle lanes makes up a reduction coefficient in bicycle stress, since the roads with higher number of lanes and high automotive speeds imply a greater stress load on the cyclist due to the high flow of motor vehicles (Sorton \& Walsh, 1994). Thus, even roads with high vehicle circulation could satisfy cyclists, as long as they are provided with specific infrastructure (Willis et al., 2013).

In Brazil, there are no clear determinations about the need for specific infrastructure, and the Brazilian manual on bicycle paths defines that "bicycle paths can serve recreational or workplace access purposes, if the flow of motor vehicles and pedestrians is small" (Brazil, 2010). The same document presents the track width as the most critical variable for sharing road space, as the width should be sufficient not to compromise the level of service of the road. In a sense, the main Brazilian technical regulation that guides the installation of cyclable infrastructure does not place the bicycle as a priority.

The first time the Brazilian government came out in favour of bicycles was in 2012, when the National Urban Mobility Policy, Federal Law $n^{\circ} 12.587$ (Brazil, 2012), was approved. This law stipulates that all Brazilian municipalities above 20.000 inhabitants must elaborate the Urban Mobility Plan, belatedly starting urban studies on motorized and non-motorized vehicle traffic.

In Rolândia, the Mobility Plan was developed in 2017, recording for the first time transport data that subsidized this work and can be used for future comparisons. These are important data, since the municipality registers a positive growth rate and increasing motorization between the years 2000 and 2020, as shown in the Table 1. 
Table 1 - Geometric rate of population and motor vehicles in Rolândia

\begin{tabular}{lllll}
\hline & $\mathbf{2 0 0 0}$ & $\mathbf{2 0 1 0}$ & $\mathbf{2 0 2 0 *}$ & Geometric growth \\
\hline Population & 49.410 & 57.862 & 66.381 & 1,03 \\
Cars & 13.768 & 27.985 & 38.946 & 1,11 \\
Motorcycles & 1.543 & 5.038 & 7.141 & 1,17 \\
\hline
\end{tabular}

Note: * - estimate. Source: ITEDES (2018).

It is important to consider that Rolândia has a segregated bicycle lane whose travel data were not considered, since there is no contact with motor vehicles. Until the publication of the Urban Mobility Plan in 2018, which offered subsidies for this study, there were no plans for bicycle path extension.

\section{Methods}

The study was conducted in a medium-sized city in southern Brazil, called Rolândia. The municipality of 66,580 inhabitants (IBGE, 2019) is located in the state of Paraná, and is part of the Metropolitan Region of Londrina.

In Brazil, 94.2\% of the municipalities have less than 100,000 inhabitants, and the highest growth rate is registered in municipalities close to the metropolitan region's pole city, as is the case of the studied municipality (IBGE, 2019). In this sense, the studied city fits in the list of those most likely to suffer from traffic and mobility problems resulting from this expansion.

By means of Geographic Information System - GIS, a map of road axes of the municipality of Rolândia was prepared. As in Turner's work (2004), each segment of the road map was analysed in Depthmap software, developed by University College London, specifically for the purpose of generating values of spatial syntax. The road segment values are illustrated in Figure 1.

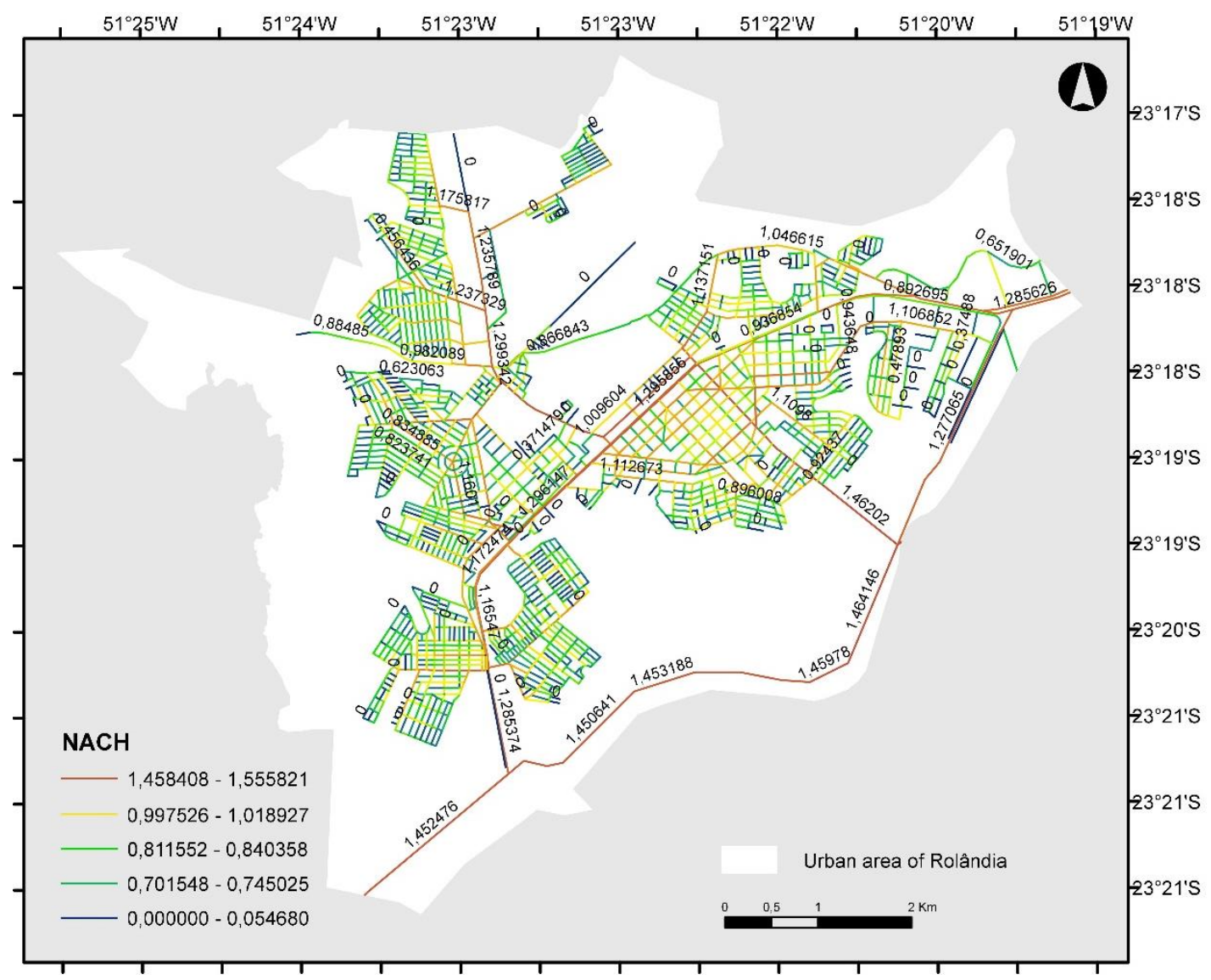

Figure 1 - NACH values extracted through Depthmap software using Rolândia-PR road centre lines. Source: the author (2020). 
Consequently, each track segment received a value, according to the relationship with the other segments of the system. These values refer to the angular integration measures (T1024_Integration) and choice (T1024_Choice). Using the equation log (value("T1024 Choice")+1)/log(value("T1024 Total Depht")+3)), the normalized choice value was also calculated, called NACH - normalized angular choice.

Over the road map, the points of accidents involving bicycles and motor vehicles between 2013 and 2017 were inserted, according to the Paraná Fire Department system (Fire Department-PR, 2018), as shown in Figure 2. All acidentes with ambulance emergency care were considered, according to the local fire service.

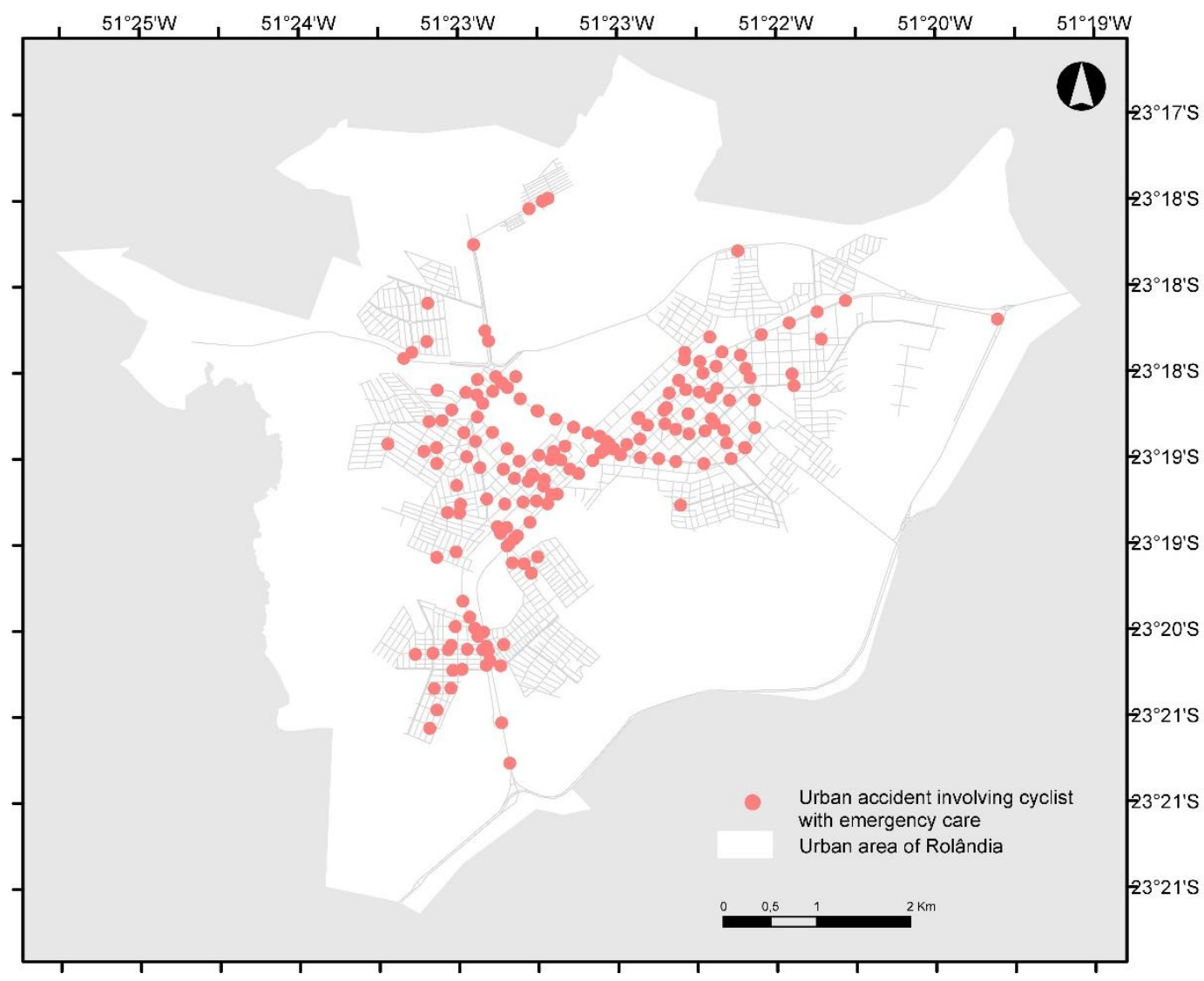

Figure 2 - Occurrence of accidents involving bicycles and ambulance emergency care in the city of Rolandia-PR between the years 2013 and 2017. Source: Fire Department-PR (2018), adapted by the author.

Finally, the study used the municipal database of a home-based origin-destination survey, conducted in the year 2017 (ITEDES, 2017). About 776 households were interviewed, where the report of all trips made the previous day was obtained. The participating households were chosen by a simple random probability sampling method, with coverage in all neighborhoods, through cadastral data provided by the municipal government.

In total, 2.731 trips were recorded, 535 of which in bicycle mode. With the point of origin and the point of destination taken from the questionnaire OD for each of the 535 trips, it was possible to indicate the route by Google MyMaps by bicycle mode. This procedure means that each origin and destination of a bicycle journey has been entered one by one in Google MyMaps, and each route has been downloaded in .kml format, in order to be used in the geoprocessing software.

This data does not necessarily indicate the exact route taken by the cyclist at that time, but constitute the largest open-platform database for the location studied, since it monitors the movement of mobile phones on the roads at speeds compatible with the mode os transport by bicycle, using artificial intelligence.

Thus, all the bike trips were spatialized through geoprocessing, using the route indicated using Google MyMaps in bike mode applied to the Quantum Gis software, as shown in Figure 3. 


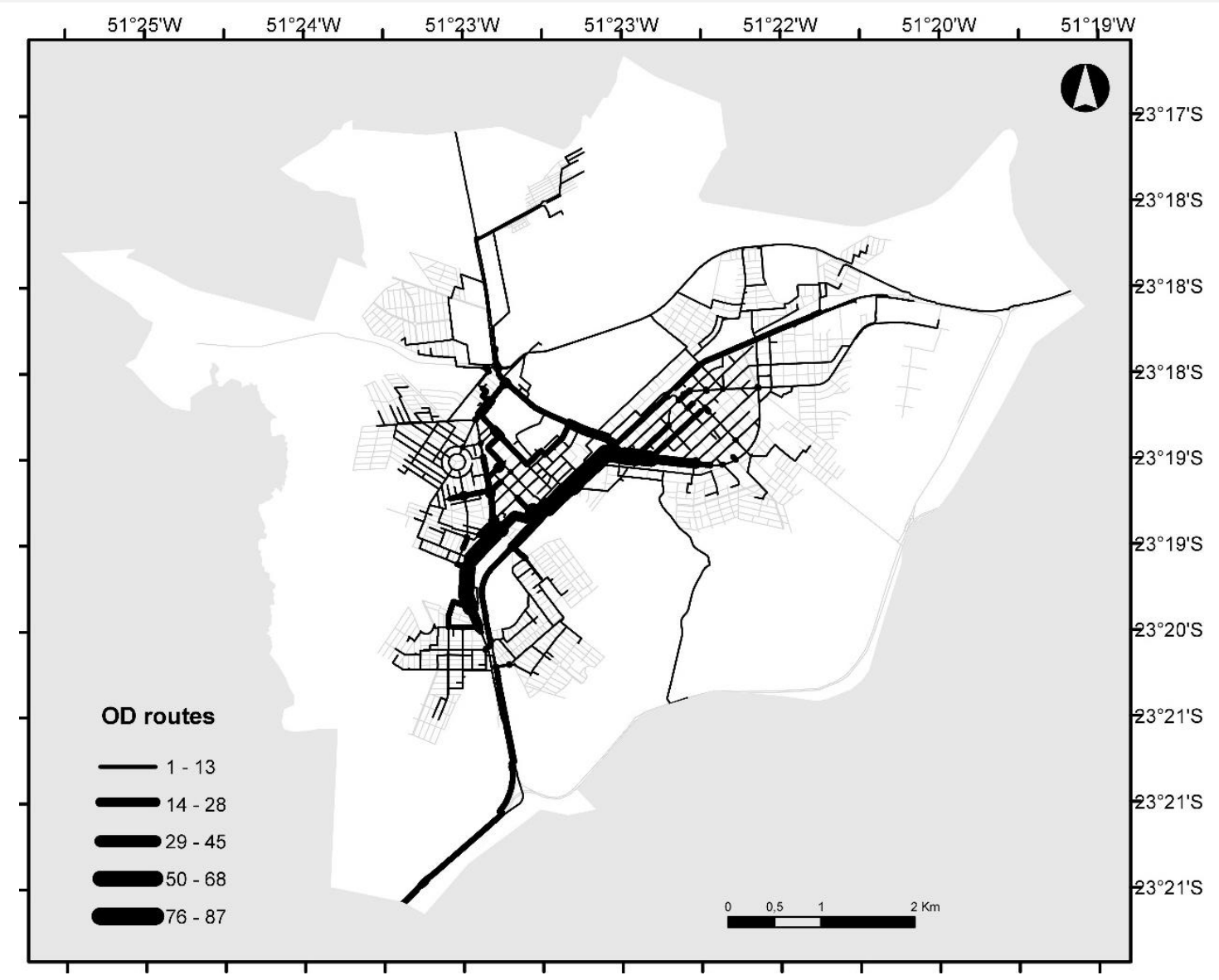

Figure 3 - Bicycle trips reported in the survey home destination of Rolandia-PR. Source: ITEDES (2018), adapted by the author.

For statistical analysis, a database with the values of choice, normalized choice, integration and superposition of routes of each straight segment where there has been the occurrence of an accident with bicycle was elaborated. Thus, considering the total of 256 occurrences of cyclists' collisions, it was processed in R 10.4 software the correlation between the values of integration and angular choice corresponding to the segment of track where the occurrence was received.

\section{Results}

Initially, a correlation was established between the syntactic values studied for normalized angular choice (NACH), angular choice (T1024_Choice), angular integration (T1024_Integration), and the accumulated number of routes in each segment. Thus, it is possible to indicate the correlation between the syntactic value and the forecast use for bicycle trip of each studied segment, according to Table 2.

Table 2 - Spearman correlation coefficients between syntactic values and number of registered routes per segment

\begin{tabular}{|c|c|c|c|c|}
\hline Variable & $\begin{array}{l}\text { Number of registered } \\
\text { routes }\end{array}$ & $\begin{array}{l}\text { NACH } \\
\text { value }\end{array}$ & T1024_Choice value & $\begin{array}{l}\text { T1024_Integration } \\
\text { value }\end{array}$ \\
\hline $\begin{array}{l}\text { Number of } \\
\text { registered routes }\end{array}$ & 1,000 & $0,188^{* *}$ & $0,176^{* *}$ & $0,282^{* *}$ \\
\hline $\mathrm{NACH}$ value & & 1,000 & $0,996^{* *}$ & $0,641^{* *}$ \\
\hline $\begin{array}{l}\text { T1024_Choice } \\
\text { value }\end{array}$ & & & 1,000 & $0,597^{* *}$ \\
\hline $\begin{array}{l}\text { T1024_Integration } \\
\text { value }\end{array}$ & & & & 1,000 \\
\hline
\end{tabular}

Note: ${ }^{* *}$ - significant to a level of significance of 0,01 . Source: Authors (2020). 
For a significance level of 0.01 , there is statistical evidence to state that the number of bike routes recorded in each segment is little related to the corresponding values of $\mathrm{NACH}$, angular choice and angular integration, although the latter value seems slightly more related.

As expected, the strongest correlation is between the standard NACH choice and the angular choice, since they start from the same calculation matrix in the dephtmap software and only reaffirm the data used are coherent.

The correlation between the routes recorded in the origin-destination survey, however, showed weak correlations, possibly because they concentrate on specific routes, unlike the syntactic values, which cover the entire municipal road network.

Furthermore, it was possible to relate the syntactic values and overlap of routes analysed by segments with the occurrence of accidents.

Through Wilcoxon's signed-rank test, it was analysed if the values of segments with accident record differ from those without accident record, to proceed with the comparisons. For this statistical study, the entire road network of the municipality of Rolândia was considered, with a total of 1,204 segments. Of that total, 1,097 segments did not present any recorded accident, and 108 segments accounted for accidents.

The Wilcoxon test is a non-parametric hypothesis test, which tests the null hypotesis, assuming that there would be no difference between the values os space syntax and the number of registered routes in road segments with and without acidentes recorded, a statement considered true until the evidence pointed in the opposite direction. The values are shown in Table 3.

Table 3 - Wilcoxon signed-rank test for angular analysis of segments with and without accidents

\begin{tabular}{|c|c|c|c|c|c|}
\hline \multirow[b]{2}{*}{ Variable } & \multicolumn{2}{|c|}{ With accidents } & \multicolumn{2}{|c|}{ Without accidents } & \multirow[b]{2}{*}{$p$ value } \\
\hline & Average & $\begin{array}{l}\text { Standard } \\
\text { deviation }\end{array}$ & Average & $\begin{array}{l}\text { Standard } \\
\text { deviation }\end{array}$ & \\
\hline $\begin{array}{l}\text { Number of registered } \\
\text { routes }\end{array}$ & 1141,62 & $(2709,41)$ & 214,57 & $(1132,35)$ & \\
\hline $\mathrm{NACH}$ value & 1,14 & $(0,27)$ & 0,98 & $(0,24)$ & $<0,01$ \\
\hline T1024_Choice value & 551197,60 & $(678261,30)$ & 137455,00 & $(304546,70)$ & \\
\hline T1024_Integration value & 607,30 & $(94,78)$ & 137455,00 & $(304546,70)$ & \\
\hline
\end{tabular}

Source: Authors (2020).

With a p value of less than 0.01 , the null hypothesis was rejected, confirming that there is a significant difference between segments with and without accident records. It can be noted that the segments that have accident records present higher averages of registered routes, value NACH, T1024_Choice and T1024_Integration.

Based on this result, a generalized linear model was elaborated to explain this relationship, and to help predict future relationships. Poisson's model was used, as it is suitable for modeling variables that involve counting data. This model applies a logarithmic function to the explanatory variables, whose result was able to explain the accidents in segments through the adjusted variables, according to the Equation 1:

Estimated number of accidents $=\exp \left[-6.148+\left(6.929 \mathrm{e}-07 \times \mathrm{xT} 1024 \_C h o i\right)+\left(6.302 \mathrm{e}-03 \times \mathrm{T} 1024 \_I n t e\right)\right]$

It can be seen that the model can explain the occurrence of accidents in the segments only with the angular choice and integration, in a quite satisfactory way, proven through the (semi-)normal probability graph analysis with simulation envelope contained in Chart 1. 


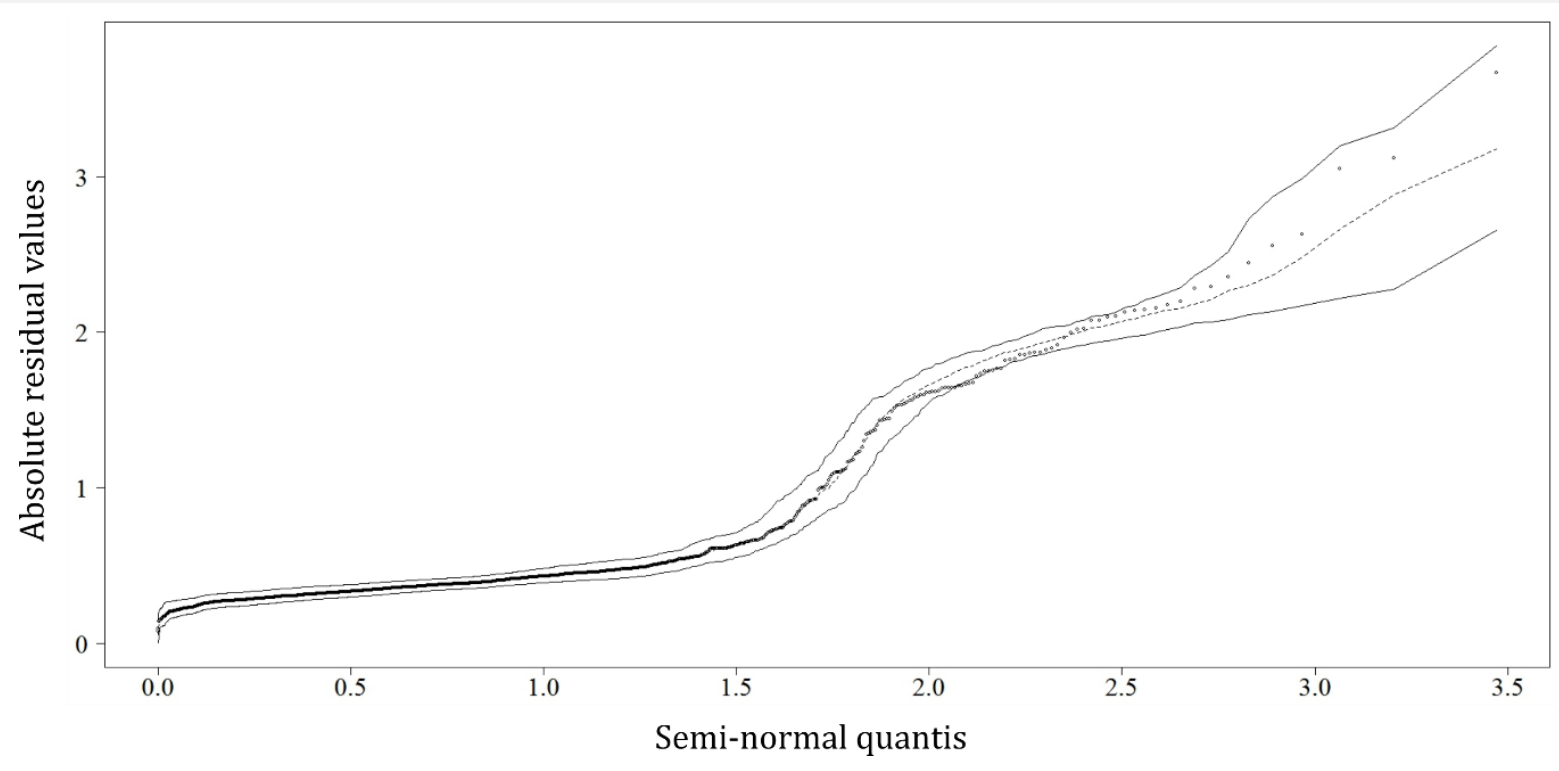

Chart 1 - (semi-)normal probability graph with simulation envelope contained. Source: Authors (2020).

The (semi-)normal probability plot with simulation envelope was created in the same way for classical regression models but using Poisson's distribution is a useful and simple tactic for checking model fit. Thus, under the correct model, the statistics obtained from the observations fall into the envelope (Cordeiro \& Demétrio, 2009).

In other words, the (semi-)normal probability plot allows to verify the assumptions of the model, and its envelope allows to take into account any correlation structure in the diagnostics.

As noted in Chart 1, the model is well adjusted, containing its values within the envelope. Returning to the data mapping, it was possible to emphasize the higher angular choice values (T1024_Choice) and angular integration (T1024_Integration).

The overlapping of the angular choice values and the points of occurrence of accidents involving bicycles revealed a correspondence between accidents on structuring roads, that is, the connections between different areas of the city, as shown in Figure 4. 


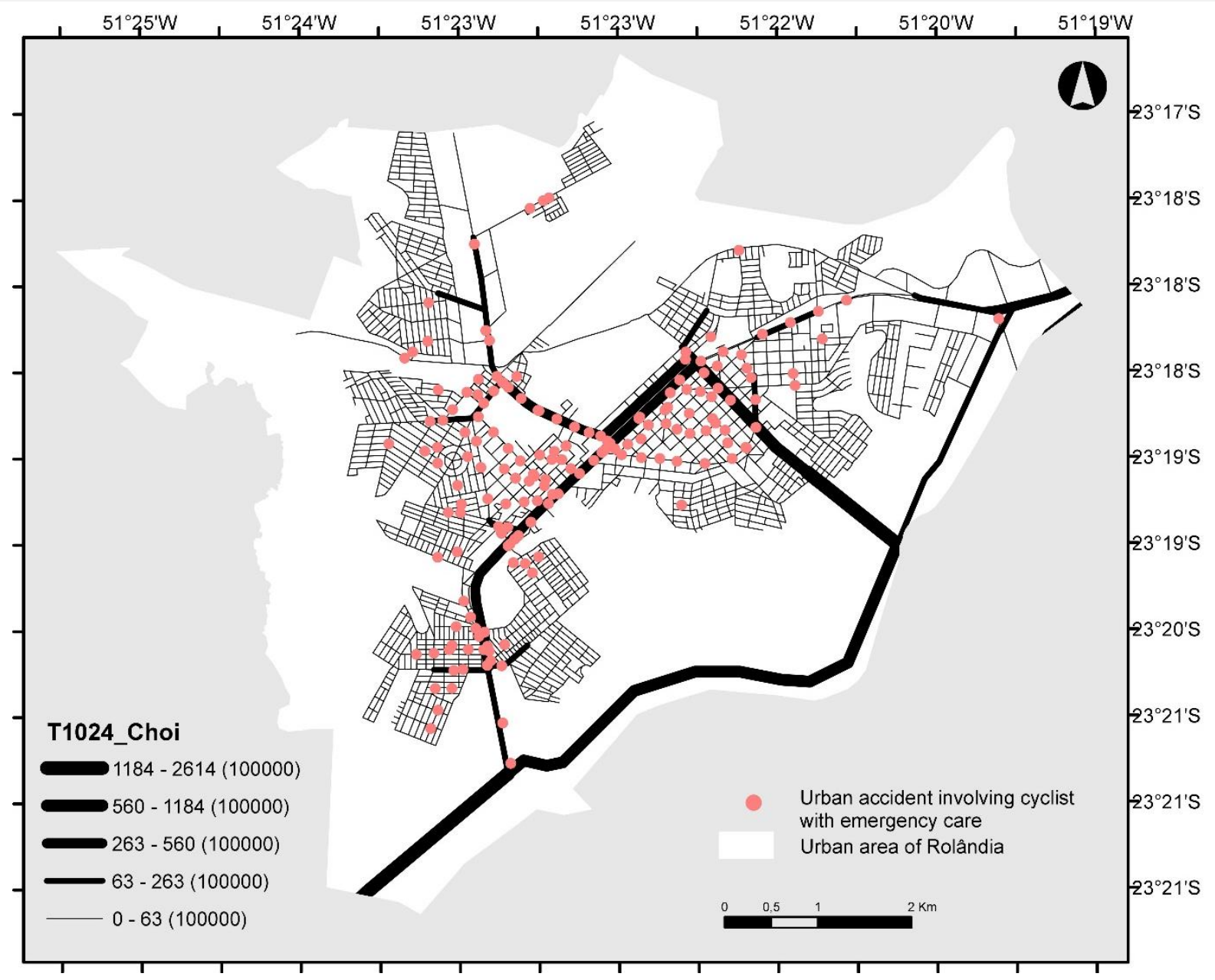

Figure 4 - Overlapping accident points with bicycles and angular choice values T1024_Choice. Source: Authors (2020).

In addition, the overlapping of accident points and angular integration values, shown in Figure 5, it is possible to see convergences in the occurrences recorded in the most central portion of the municipality. 


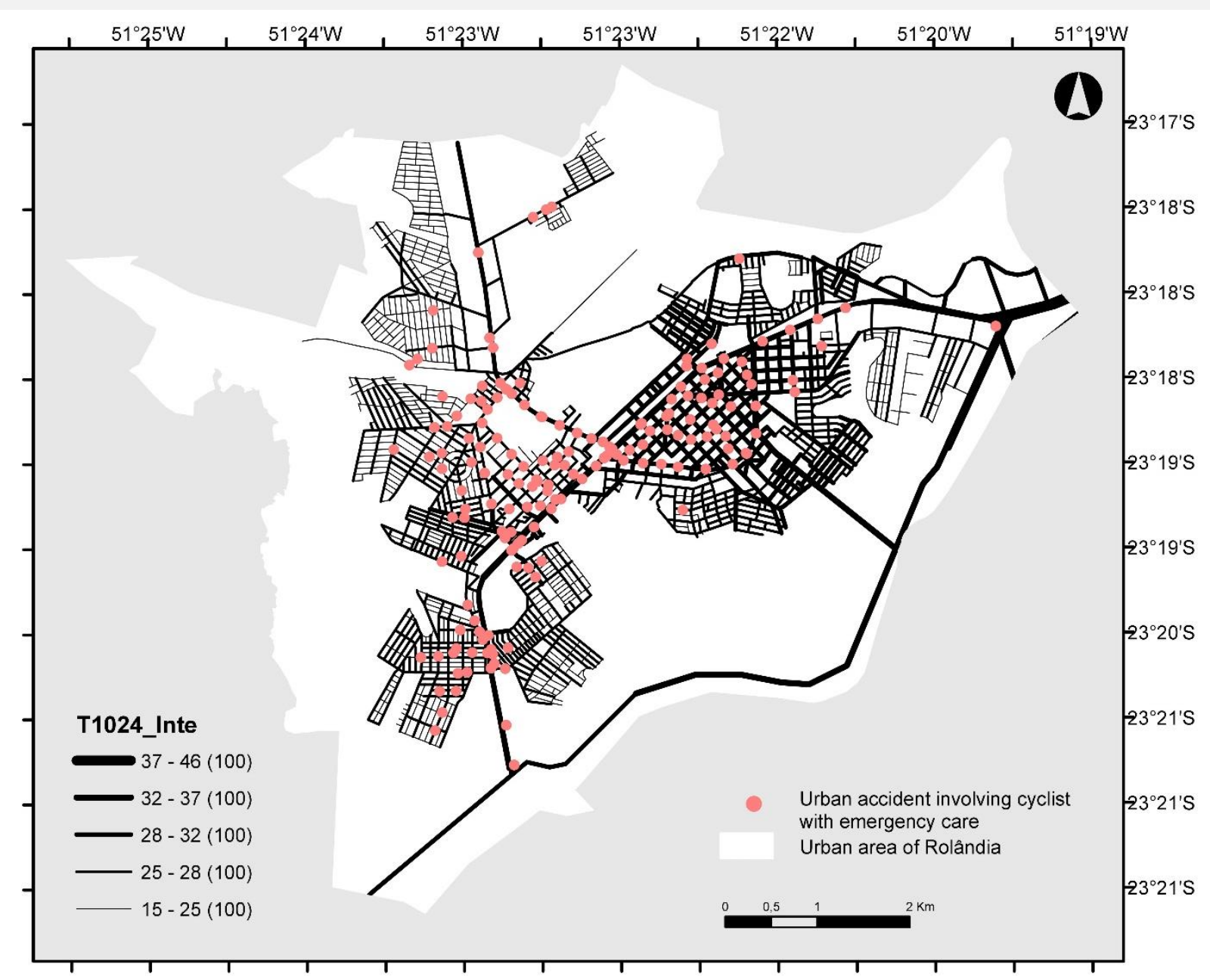

Figure 5 - Overlapping accident points with bicycles and angular choice values T1024_Integration. Source: Authors (2020).

Although in the visual analysis on a map there are accidents in intermediate values of choice and angular integration, the logarithmic equation (exp [-6.148+(6.929e-07xQ1024_Choice) + (6.302e-03 x T1024_Integration)] is accurate to the results.

\section{Discussion of results}

This research was guided to the formulation of a model for predicting accidents involving cyclists, which, among the range of variables that included the number of routes recorded, determined that the values of space syntax related to choice and angular integration are already sufficient to statistically explain the number of accidents in each segment analysed.

In this paper, this means the points of occurrence of accidents were little related to the 535 trips reported in the home destination survey. It could be expected that the road segments with the highest travel records would present a distinct rate of accidents, which did not occur. Surprisingly, the angular values of choice and integration, when combined, explain the totality of accidents for each road segment, throughout the entire municipal urban network.

Such indications may configure a new potential for urban morphology studies, involving the road safety of non-motorised modes of transport. In this way, it is proven that the applications of space syntax to urban and transportation planning have not yet been depleted.

By the use of spatial syntax, the accessibility of routes is recognized by integration values, where areas with greater possibility of routes receive higher values. To calculate the choice, all points of the urban network are treated as origins and destinations, and the most direct connections receive higher values, indicating more agile and efficient routes for the bike trip. 
In summary, the routes with the greatest variability of routes (integration) and the most direct routes (choice) registered the greatest number of accident occurrences. These two variables, integration and choice, composed the accident prediction model presented in this work.

In this regard, it is stated that the most direct and accessible connections of cycle routes are more prone to collisions between vehicles and cyclists. This fact opens the discussion about the best places for the implementation of bike paths, cycle paths and shared lanes.

The procedure for identifying more connected and direct routes using space syntax is quite simple and can be performed entirely in open source software, Depthmap. This tool can point out the most efficient routes for any mode of travel, with the decision on which means of transport should be a priority with increased safety.

These findings have important implications in the planning of bicycle facilities in a developing country context. First, the influences of the choice and integration of roads on bicycle safety are verified, and there is a paradox point in this.

The values of choice and integration have a static nature, because they are removed through a computational algorithm of urban network analysis and proved sufficient for the prediction of accidents involving cyclists and motor vehicles. In turn, the activity record of the origin-destination survey, with the real movement dynamics, were not promising for accident predition.

From this perspective, the spatial syntax variables were more explanatory than the actual recording of bicycle transport. The possibilities, not yet exhausted, of using spatial syntax as a tool for urban planning should be highlighted and should be considered in studies of active modes of transport. It is suggested the importance of studies in different urban networks, of variable complexities, in order to verify the validity of the equation presented in different contexts.

The second implication is about the priority route detection strategy. Since the most integrated and connected routes are those that produce the most accidents with cyclists, there should also be provided with specific infrastructure to ensure the safe circulation of this modal. In this regard, the implementation of bicycle paths exclusively on roads with low vehicle circulation is not the most strategic solution for the development of bicycle transport.

Although the travel data from the home destination survey did not serve for the accident prediction model, it does contain some essential information. In a household questionnaire with statistical approach and total coverage of the municipality, 2.731 trips were recorded, of which 535 were in bicycle mode.

This means that $19.6 \%$ of all trips are made by bicycle, putting the city of Rolândia in a European level of participation of bicycle as a mode of transport (Pucher \& Buehler, 2008), but with lower travel conditions, since it does not present urban policies that favor this mode of travel.

\section{Conclusions}

In the context of accelerated motorisation, governments should work to increase safety and mobility for all road users, especially those at greatest risk, such as cyclists. It is a matter of urgency to support infrastructure and bicycle-oriented planning to avoid a dramatic shift to motorised modes, which would exacerbate transport problems and accentuate the inequality of affordability in transport systems.

In Brazil, there are no specific national guidelines to assist public managers in identifying priority routes for the construction of cycling infrastructure, nor analytical methods to recognize the routes that most need attention as to the safety of the bicycle user. The country appears to be following outdated traffic engineering guides, being marked by retrograde steps in relation to the development of bicycle transport (IPEA, 2017).

Without determining scientific criteria that clarify the importance of determining priority routes with increased safety for cyclists, it is possible that bicycle use will decay in Brazil rather than be reinforced. 


\section{References}

Ahmad, S., \& de Oliveira, J. P. (2016). Determinants of urban mobility in India: lessons for promoting sustainable and inclusive urban transport in developing countries. Transport Policy, 50, 106-114.

https://doi.org/10.1016/j.tranpol.2016.04.014.

Boullier, D., \& Crépel, M. (2014). Vélib and data: a new way of inhabiting the city. urbe. Revista Brasileira de Gestão Urbana, 6(1), 47-56. https://doi.org/10.7213/urbe.06.001.SE03.

Buehler, R., \& Dill, J. (2015). Bikeway Networks: A Review of Effects on Cycling. Transport Reviews, 36(1), 9-27. https://doi.org/10.1080/01441647.2015.1069908.

Brazil. (2010). Manual de projeto geométrico de travassias urbanas. Rio de Janeiro: Ministério dos Transportes/DNIT.

Brazil. (2012, January 3). Law 12.587, of January 3, 2012. Estabilishes the guidelines for the National Policy on Urban Mobility. Brasília: Federal Official Gazette, section 1, page 4.

Celis-Morales, C. A., Lyall, D. M., Anderson, J., Steel, L., Guo, Y., Maldonado, R., Mackey, D. F., Pell, J. P., Sattar, N., \& Gill, J. M. R. (2017). Association between active commuting and incident cardiovascular disease, cancer, and mortality: prospective cohort study. The BMJ, 357 (j1456). https://doi.org/10.1136/bmj.j1456.

Cooper, C. H. V. (2017). Using spatial network analysis to model pedal cycle flows, risk and mode choice. Journal of Transport Geography, 58, 157-165. https://doi.org/10.1016/j.jtrangeo.2016.12.003.

Cordeiro, G. M. C., \& Demétrio, C. G. B. (2009). Modelos lineares generalizados e extensões. Piracicaba: ESALQ/USP.

DepthmapX development team. (2017). DepthmapX (Version 0.6.0).

Duarte, F., Procopiuck, M., \& Fujioka, K. (2014). “No bicycle lanes!” Shouted the cyclists. A controversial bicycle project in Curitiba, Brazil. Transport Policy, 32, 180-185. https://doi.org/10.1016/j.tranpol.2014.01.010.

Eliou, N., Galanis, A., \& Proios, A. (2009). Evaluation of the bikeability of a Greek city: Case study "City of Volos". WSEAS Transactions on Environment and Development, 5(8), 545-544. Retrieved on 5 April 2020 from http://hdl.handle.net/11615/27357.

Ellison, R. B., \& Greaves, S. (2011). Travel Time Competitiveness of Cycling in Sydney, Australia. Transportation Research Record, 2247, 99-108. https://doi.org/10.3141/2247-12.

Ferraz, I. S., Gomes, N. S., Kobs, F. F., Silva, M. C. da., \& Casagrande Júnior, E. F. (2017). Avaliação do uso da primeira Via Calma em Curitiba/PR para ciclomobilidade. urbe. Revista Brasileira de Gestão Urbana, 9(2), 341-353. https://doi.org/10.1590/2175-3369.009.002.ao13.

Fire Department-PR. Sistema de registro e estatística de ocorrências. Retrieved on 10 September 2019 at www.bombeiroscascavel.com.br.

Gössling, S. (2016). Urban transport justice. Journal of Transport Geography, 54, 1-9. https://doi.org/10.1016/j.jtrangeo.2016.05.002.

Guthrie, N., Davies, D. G., \& Gardner, G. (2001). Cyclist's assesments of road and traffic conditions: the development of a cyclability index. TRL Report, 490. Retrieved on 10 March 2020 at https://trid.trb.org/view/1161148.

Habib, K. N., Mann, J., Mahmoud, M., \& Weiss, A. (2014). Synopsis of bicycle demand in the City of Toronto: Investigating the effects of perception, consciousness and comfortability on the purpose of biking and bike ownership. Transportation Research Part A, 70, 67-80. https://doi.org/10.1016/j.tra.2014.09.012.

Halldórsdóttir, K., Nielsen, O. A., \& Prato, C. G. (2017). Home-end and activity-end preferences for access to and egress from train stations in the Copenhagen region. International Journal of Sustainable Transportation, 11, 776-786.

https://doi.org/10.1080/15568318.2017.1317888.

Hillier, B. (1996). Space is the machine. Cambridge: Cambridge University Press.

Hillier, B., Yang, T., \& Turner, A. (2012). Normalising least angle choice in Depthmap and how it opens up new perspectives on the global and local analysis of city space. The Journal of Space Syntax, 3(2), 155-193. Retrieved on 10 March 2020 at http://128.40.150.106/joss/index.php/joss/article/view/141/pdf.

Instituto Brasileiro de Geografia e Estatística - IBGE. (2019). Estatísticas sociais. Rio de Janeiro: IBGE. Retrieved on 10 March 2020 at www.ibge.gov.br 
Instituto de Pesquisa Econômica Aplicada - IPEA. (2017). Cidades cicláveis: avanços e desafios das políticas cicloviárias no Brasil. Brasília: Ipea.

Instituto de Tecnologia e Desenvolvimento Econômico e Social - ITEDES. (2017). Pesquisa origem-destino domiciliar de Rolândia-PR. Rolândia: Prefeitura Municipal.

Instituto de Tecnologia e Desenvolvimento Econômico e Social - ITEDES. (2018). Plano de mobilidade urbana de RolândiaPR. Rolândia: Prefeitura Municipal. Retrieved on 10 March 2020 at http://rolandia.pr.gov.br.177-126-17685.weblinesistemas.com/arquivos_cliente/PlanMob_completo.pdf.

Krecl, P., Cipoli, Y. A., Targino, A. C., Toloto, M., Segersson, D., Parra, Á., Polezer, G., Godoi, R. H. M., \& Gidhagen, L. (2019). Modelling urban cyclists' exposure to black carbon particles using high spatiotemporal data: A statistical approach. Science of The Total Environment, 679, 115-125. https://doi.org/10.1016/j.scitotenv.2019.05.043.

Law, S., Sakr, F. L., \& Martinez, M. (2014). Measuring the changes in aggregate cycling patterns between 2003 and 2012 from a space syntax perspective. Behavioral Sciences, 4(3), 278-300. https://doi.org/10.3390/bs4030278.

Litman, T. (2014). Transport land requirements spreadsheet. Victoria: Victoria Transport Policy Institute.

Lowry M., \& Loh T. H. (2017). Quantifying bicycle network connectivity. Preventive Medicine, 95, S134-S140. https://doi.org/10.1016/j.ypmed.2016.12.007.

Lowry, M. B., Callister, D., Gresham, M., \& Moore, B. (2012). Assessment of communitywide bikeability with bicycle level of service. Transportation Research Record, 2314, 41-48. https://doi.org/10.3141/2314-06.

Lowry, M. B., Furth, P., \& Hadden-Loh, T. (2016). Prioritizing new bicycle facilities to improve low-stress network connectivity. Transportation Research Part A, 86, 124-140. https://doi.org/10.1016/j.tra.2016.02.003.

Manum, B., Nordström, T., Gil, J., Nilsson, L., \& Marcus, L. (2017). Modelling bikeability: space syntax based measures applied in examining speeds and flows of bicycling in Gothenburg. In Proceedings of the $11^{\text {th }}$ Space Syntax Symposium (p. 89.1-89.16). Lisbon: XI SSS.

Maricato, E. (2014). O impasse da política urbana no Brasil. (3a Ed.). Petrópolis: Vozes.

McCahill, C., \& Garrick, W. (2008). The applicability of space syntax to bicycle facility planning. Transportation Research Record, 2074, 46-51. https://doi.org/10.3141/2074-06.

McNeil, N. (2011). Bikeability and the twenty-minute neighborhood: how infrastructure and destinations influence bicycle accessibility. Transportation Research Record, 2247, 53-63. https://doi.org/10.3141/2247-07.

Minikel, E. (2012). Cyclist safety on bicycle boulevards and parallel arterial routes in Berkeley, California. Accident Analysis \& Prevention, 45, 241-247. https://doi.org/10.1016/j.aap.2011.07.009.

Nielsen, T. A. S., Olafsson, A. S., Carstensen, T. A., \& Skov-Petersen, H. (2013). Environmental correlates of cycling: Evaluating urban form and location effects based on Danish micro-data. Transportation Research Part D, 22, 40-44. https://doi.org/10.1016/j.trd.2013.02.017.

Nordström, T, \& Manum, B. (2015). Measuring bikeability: space syntax methods applied in planning for improved conditions for bicycling in Oslo. In Proceedings of the 10th Space Syntax Symposium (p. 77.1-77.14). London: X SSS.

Oliveira, V. (2016). Urban morphology. An introduction to the study of the physical form of cities. Switzerland: Springer.

Pucher, J., \& Buehler, R. (2008). Making cycling irresistible: lessons from the Netherlands, Denmark and Germany. Transport Reviews, 28(4), 495-528. https://doi.org/10.1080/01441640701806612.

Raford, N., Chiaradia, A., \& Gil, J. (2007). Space syntax: the role of urban form in cyclist route choice in central London. In Transportation Research Board $86^{\text {th }}$ Annual Meeting. Washington: TRB.

Schoner, J. E., Cao, J., \& Levinson, D. M. (2015). Catalysts and magnets: built environment and bicycle commuting. Journal of Transport Geography, 47, 100-108. https://doi.org/10.1016/j.jtrangeo.2015.07.007.

Sorton, A., Walsh, T. (1994). Bicycle stress level as a tool to evaluate urban and suburban bicycle compatibility.

Transportation Research Record, 1438, 17-24. Retrieved on 10 March 2020 at

http://onlinepubs.trb.org/Onlinepubs/trr/1994/1438/1438-003.pdf.

Steil Ferraz, I., Simões Gomes, N., Kobs, F., Correa da Silva, M., \& Fassi Casagrande Júnior, E. (2017). Avaliação do uso da primeira Via Calma em Curitiba/PR para ciclomobilidade. urbe. Revista Brasileira de Gestão Urbana, 9(2).

https://doi.org/10.1590/2175-3369.009.002.ao13. 


\section{Routing for safer rides}

The World Bank. (2002). Cities on the move. A World Bank urban transport strategy review. Washington: TWITR. Retrieved on 10 March 2020 at https://documents.worldbank.org/pt/publication/documents-

reports/documentdetail/928301468762905413/cities-on-the-move-a-world-bank-urban-transport-strategy-review.

Turner, A. (2004). Dephtmap 4 - A Researcher's Handbook. Bartlett School of Graduate Studies. Londres: UCL. Retrieved on 10 March 2020 at https://discovery.ucl.ac.uk/id/eprint/2651.

Vandenbulcke, G., Thomas, I., \& Panis, L. I. (2014). Predicting cycling accident risk in Brussels: A spatial case-control approach. Accident Analysis and Prevention, 62, 341-357. https://doi.org/10.1016/j.aap.2013.07.001.

Vedel, S. E., Jacobsen, J. B., \& Skov-Petersen, H. (2017). Bicyclists' preferences for route characteristics and crowding in Copenhagen - A choice experiment study of commuters. Transportation Research Part A, 100, 53-64. https://doi.org/10.1016/j.tra.2017.04.006.

Wahlgren, L., \& Schantz, P. (2011). Bikeability and methodological issues using the active commuting route environment scale (ACRES) in a metropolitan setting. BMC Medical Research Methodology, 11(6), 1-20. https://doi.org/10.1186/14712288-11-6.

Wahlgren, L., \& Schantz, P. (2012). Exploring bikeability in a metropolitan setting: stimulating and hindering factors in commuting route environments. BMC Public Health, 12(168). https://doi.org/10.1186/1471-2458-12-168.

World Health Organization - WHO. (2013). Global status report on road safety. Switzerland: World Health Organization.

Willis, D. P., Manaugh, K., \& El-Geneidy, A. (2013). Uniquely satisfied: Exploring cyclist satisfaction. Transportation Research Part F, 18, 136-147. https://doi.org/10.1016/j.trf.2012.12.004.

Editor: Fábio Duarte

Received: Apr. $7^{\text {th }}, 2020$

Approved: Dec. 20th, 2020 